It is a matter of regret that space precludes further discussion of this careful, and, in inferences, conservative piece of experimental analysis. The author reaches the general conclusion that the distribution of the attention between the two extents or within either extent doubtless most influences the judgments; she represents essentially, therefore, an 'Aufmerksamkeitstheorie.'

YALE UnIVERSITY

Roswell P. Angier

\title{
MENTAL HEALING
}

Three Thousand Years of Mental Healing. George Barton Cutten.

New York: Charles Scribner's Sons, 1911. Pp. viii +318.

President Cutten has given us in this book a most extensive and excellently arranged compilation of the phases and practices of the healing art which we now know as 'mental.' The volume is not for the specialist in these matters, the text being predominantly expository and "dealing more especially with the historical side of the subject."

Stating the common law underlying all forms of mental healing to be: "My body tends to adjust itself so as to be in harmony with my ideas concerning it," and pointing out that there is no 'best form' of mental healing, the author proceeds to show that the diversity of means employed throughout the ages has been such as to meet the wide diversities of custom, belief, and inherited superstition that at any given moment were prevailing.

From the early practices in Egypt and in India, among the Jews and among the Greeks, the reader is carried through successive ages down to the various cults of the present day. In general the association of mental healing with religion is held to have been advantageous, since "the devout attitude of mind is one most favorable for the working of suggestion." The twofold influence of the church, on the one hand in increasing human effort in alleviating illness and on the other in perpetuating the easy superstitions of mankind and thus delaying the development of medical science, is well set forth. The non-religious 'healer,' it is pointed out, has been more ready to recognize the limitations of his power and has thus been less obstructive to advances in the healing art than his confrère who has worked in the name of religion.

Separate chapters - and these perhaps the best of the bookare devoted to 'Relics and Shrines,' 'Talismans,' 'Amulets,' and 
'Charms.' The material is presented with much fulness but always with discrimination and clearness of exposition. The reviewer is acquainted with no other book from which one may so readily gain an adequate impression of the controlling sway among all peoples at all times of formularies and ceremonies, of incantations and exorcisms, and of all the practices which reveal the trusting faith in the benign power of inanimate objects, nauseous and revolting doses, and absurd rites. Such an historical survey should certainly be read by all those-and there are still not a few of them-who regard the various healing cults as distinctly modern innovations.

The value of the book lies largely in its compilation and convenient arrangement of scattered material and in its marshalling of curious recipes, half sensible or utterly grotesque, to which the credulous afflicted of the past have had recourse. The absurdities of the present may thus be brought into direct comparison, in the mind of the reader, with the (happily) greater absurdities that have been outlived.

The volume closes with chapters, mostly biographical, entitled 'Mesmer and After,' and 'The Healers of the Nineteenth Century.' There is an excellent index.

A. H. P.

\section{PSYCHOLOGY OF ADVERTISING}

Principles of Advertising: A Systematic Syllabus of the Principles of Advertising. Daniel Starch. Madison, Wis.: The University Coöperative Co., I9Io. Pp. 67.

The content of the volume is adequately expressed in the subtitle: it is thoroughly systematic and it is merely a syllabus. It is a work on applied psychology. There still survives among psychologists a prejudice against applied psychology. This prejudice would be justified if 'applied' psychology meant merely the attempt to apply established psychological laws or principles to such things as teaching, healing and selling. In so far, however, as applied psychology advances the science of psychology it should be given a place of honor by the professional psychologist. It is the conviction of the reviewer that applied psychology has demonstrated its scientific value. Educational psychology has advanced our knowledge of the processes summarized under the headings of memory and of the learning processes. Psychotherapy has stimulated research on the subjects of suggestion and the relation of the mind to the body. Animal psychology has made distinct contributions to the study of 